In our survey ${ }^{2}$ we found in the five types of schools where a cold buffet was offered that the average food per plate provided $10-25 \%$ less than the hot meal in the same school both for energy and for protein. At that time we were considering whether or not the target was being achieved and this greater shortfall with the cold buffet indicated that it was not getting as near the target as was the hot meal. However, since children vary so much in their needs perhaps, when offered a choice, they select what they need rather than what the nutritionist thinks that, on average, they ought to have.

On this basis there might be an actual saving in the cost of food if the children were offered a choice instead of the traditional approach. Cerainly sandwiches, beans on toast, and similar snacks which are usually looked down on can be as nutritious as a traditional hot meal.

Department of Food Science and
Nutrition,
Queen Elizabeth College,
London W8 7AH
' Department of Education and Science, Nutrition in
Schools, London, HMSO, 1975.
'Bender, A E, Harris, M C, and Getreuer, A, British
Medical fournal, 1977, 1, 757.
${ }^{3}$ Bender, A E, Magee, P, and Nash, A H, British
Medical fournal, 1972, 2, 383.
' Essex-Cater, A, and Robert-Sargeant, S, Health and
Social Service fournal, 1975, 85, 758. McCance and
'Paul, A A, and Southgate, D A T, McCand A
Widdowson's The Composition of Foods, 4th edn,
p 266. London, HMSO, 1978.

\section{Care of children in general practice}

SIR,-Dr Stuart Carne's paper (21 July, p 190) is certainly an interesting account of one man's practice of child are in general practice. There are, however, some points that he raised that I would take issue with.

As I understand him, he criticises the hospital paediatric specialist for offering only episodic illness care. Yet, if I read Dr Carne correctly, by offering an illness care service on to which seems to be grafted a method of surveillance contriving to assess overall development as well as vision and hearing carried out on sick or recovering children, he seems guilty of offering just such a service, based as it is on the episodic illness care service of conventional general practice. I also concur with Dr E M Davies (18 August, p 443) in her doubts the wisdom of carrying out a surveillance examination on a sick or recovering child.

It also seems that $\mathrm{Dr}$ Carne is unclear about the real aims of offering a surveillance service for under-5s. Those whose hobby horse it is-and I'm proud to be numbered among them-never forget why such a service was set up in the first place in this country. In the developing world the lessons are there for all to see. When more than $80 \%$ of the under-5-year children and their parents in any country are making regular visits to the clinics of such a programme with a more than $80 \%$ immunisation rate combined with sound nutritional advice, an open-door service for illness care, and a developmental surveillance service, changes occur. The benefits are that mortality and morbidity decline, the growth of the individual child improves, and the demands on the curative services fall.

In this country today there are very few of us who can claim to have achieved these objectives. The general practitioner paediatrician as proposed in the Court Report is certainly an excellent starting point from which to evolve such a nationwide programme. It is already a good sign that a few GPs are running such programmes and many more are actively exploring the possibility of doing so, despite the rejection of the concept by our leaders.

Finally, I would agree with the other correspondents that there is a need for further education. All three services that care for children-the community health services, the hospital services, and the general practitioner services - have a lot to learn from each other. Mutual respect is built on trust, and perhaps it is because we do not trust the quality of each other's skills that some of us believe that when consultants learn something about this aspect of medical care all will then be well: I disagree. My opinion is that we can and must all learn from each other. Then and only then can we start improving child care in this country.

Graham Curtis Jenkins Ashford, Middx TW15 2TU

\section{Referral of mothers and infants for} intensive care

SIR,-In their excellent paper on the referral of mothers and infants for intensive care (18 August, $p$ 414), Anthea M Blake and her colleagues seriously underestimate the extent of the antenatal referral service that would have to be provided to cause a reduction in regional perinatal mortality rates. In a region with 40000 annual births, 120 lives would have to be saved to reduce the rate by three points. It is impossible to be sure of the outcome in a baby of a referred mother had the birth taken place in the district general hospital instead of the perinatal centre. It is fair to assume that babies who develop incipient respiratory failure would die if they were nursed in a district general hospital without facilities for mechanical ventilation. In the authors' analysis of babies of referred mothers, for each baby who required mechanical ventilation, a further two did not. Assuming an optimistic $80 \%$ survival rate for ventilated babies I calculate that the saving of 120 lives would entail the referral of at least 450 mothers annually (not allowing for multiple pregnancy). Yet the University College Hospital unit only received a quarter of this figure during a three-year period.

There is insufficient evidence that the availability of procedures other than mechanical ventilation (such as parenteral nutrition, continuous positive airways pressure, and continuous blood gas analysis) has such an ameliorating effect on perinatal mortality rates that transfer in utero is justified for all babies who might require such care. If that were so, many perinatal centres would be required for each region. We can also only speculate on the magnitude of any beneficial effect of neonatal care on the incidence of long-term handicap.

It is not difficult to predict the birth of a low-birthweight baby. It is harder to predict antenatally the occurrence of incipient respiratory failure in such a baby. Those pregnancies most likely to culminate that way are often the ones most likely to give rise to an obstetric emergency during transfer (for example, antepartum haemorrhage, severe pre-eclamptic toxaemia). It would be a retrograde step if we sacrificed maternal wellbeing in our efforts to secure neonatal health.
When comparing the neonatal mortality rate in babies of referred mothers with the national figures one should remember that the latter are likely to be over-represented by socially deprived mothers who received virtually no antenatal care. Before a system of antenatal referral widely develops I hope all the implications will be carefully debatednot the least being the effect on the education of midwives, obstetricians, and paediatricians working in district general hospitals. Surely our priorities ought to be: firstly, an improvement of neonatal staffing and facilities in district general hospitals; secondly, a network of neonatal flying squads to transfer babies with respiratory failure to a regional perinatal centre; and, thirdly, a very selective antenatal referral system for certain women in whom elective caesarian section is necessary before term and fetal lung maturation is uncertain or inadequate.

Malcolm L Chiswick

St Mary's Hospital,
Manchester M13 OJH

\section{Breast or bottle}

SIR,-The recent correspondence (25 August, p 492; 8 September, p 609) in which your readers gave a first-hand account of their success or failure in breast-feeding has a number of messages for those engaged in care of the newborn.

Although claims have been made in the past that successful breast-feeding may be established by virtually every mother I doubt whether this is true in our society in 1979. On the Isle of Wight we have recently studied all infants born during a 12-month period and are attempting to relate problems in the first year of life to the mode of feeding. Approximately 1000 infants were included in the study and most of the mothers kept a diary of problems they attributed to feeding. Reading these diaries has been a salutary experience, for, although $60 \%$ of Isle of Wight mothers are breast-feeding at the end of the first week after the birth of the infant and 33\% after three months, such success is not easily achieved. The health visitors recorded "inadequate lactation" as the commonest cause for abandoning breast-feeding; and, although this may sometimes be the most convenient excuse for the mother giving up something she did not really wish to do, my study of the diaries convinces me this often is the true explanation.

I suspect that the pressures and demands of modern living, even on this peaceful island, make breast-feeding very difficult for many mothers. The Isle of Wight study confirms that breast-feeding protects against certain allergic diseases developing in the first year of life and the increased prevalence of infection in the bottle-fed baby has been well established.

The question arises whether, if breastfeeding is impossible, cows' milk is the best alternative. Perhaps we should consider the wider use of hypoallergenic feeds for the substantial numbers of mothers unable to breast-feed.

Shorwell,
Isle of Wight PO30 3JG

DAvid W HIDE

SIR,-I was amused by Dr Paula H BoltonMaggs's account in Personal Paper (11 August, p 371) of her experiences in establishing 